\title{
PUTIN v. THE PEOPLE
}




\section{Samuel A. Greene and Graeme B. Robertson}
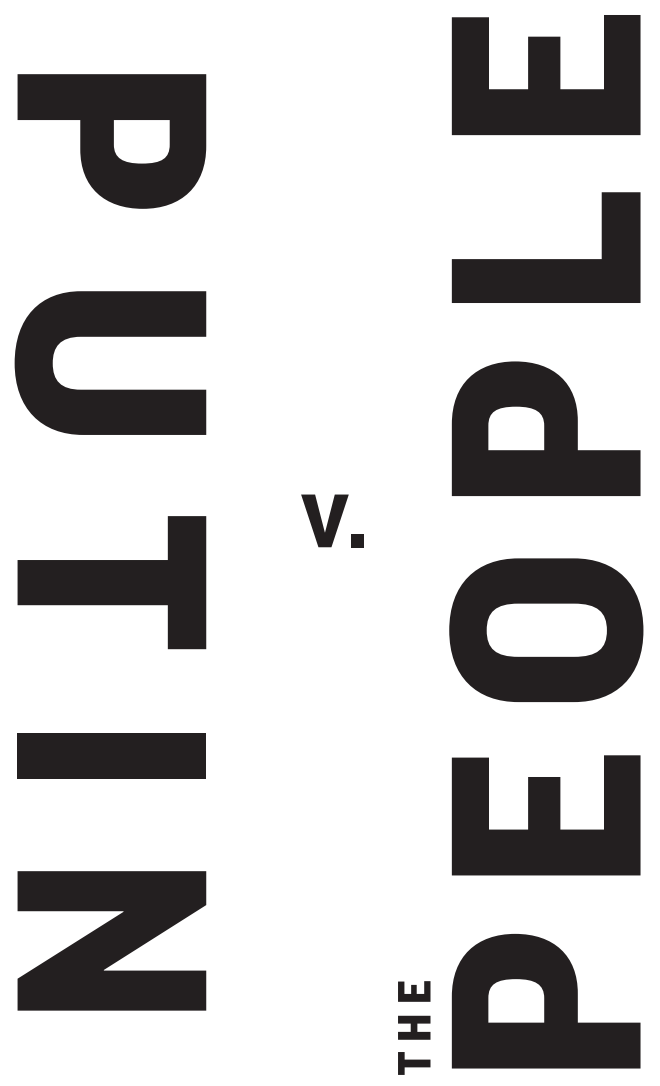

The Perilous Politics of a Divided Russia

YALE UNIVERSITY PRESS

NEW HAVEN AND LONDON 


\section{To Elyana and Anya \\ -SG}

\section{To Ceci, Tomás and Mili \\ -GR}

Copyright (C) 2019 Samuel A. Greene and Graeme B. Robertson

All rights reserved. This book may not be reproduced in whole or in part, in any form (beyond that copying permitted by Sections 107 and 108 of the U.S. Copyright Law and except by reviewers for the public press) without written permission from the publishers.

For information about this and other Yale University Press publications, please contact:

U.S.Office: sales.press@yale.edu yalebooks.com

Europe Office: sales@yaleup.co.uk yalebooks.co.uk

Set in Adobe Caslon Pro Regular by IDSUK (DataConnection) Ltd Printed in Great Britain by TJ International Ltd, Padstow, Cornwall

Library of Congress Control Number: 2019932772

ISBN 978-0-300-23839-6

A catalogue record for this book is available from the British Library.

10987654321 